\title{
DEPOSITIONAL LANDFORMING PROCESSES AT THE SNOUTS OF FIVE SURGING GLACIERS IN VESTSPITSBERGEN
}

\section{(Abstract only)}

by

\author{
D. G. Croot
}

(Plymouth Polytechnic, Drake Circus, Plymouth, Devon PL4 8AA, England)

\section{ABSTRACT}

Recent work by Clapperton (1-975) proposes that the rapid rates of advance experienced by glaciers which surge may lead to enhanced debris incorporation, increased compressive flow near the glacier snout at the point of maximum extension, and to the upward translation and vertical stacking of debris near the glacier snout and margin. Five glaciers in Spitsbergen (Battyebreen, Holmströmbreen, Lisbetbreen, Vonbreen, Elnabreen) display morphological features which are widely accepted as being diagnostic of surging glaciers,

Results of detailed observations regarding the nature, distribution, melt-out, and reworking of englacial debris at Battyebreen are presented. Basally derived till is brought to the surface of the glacier in narrow lateral and terminal belts, no more than $100 \mathrm{~m}$ wide. Within this zone, (i.e. up-valley from the snout and towards the valley centre) the ice is debrisfree with the exception of small amounts of englacial debris which form the core of lobate medial moraines. Differential ablation of debris-free and debris-rich ice leads to the production of a topographic basin within which melt-out and reworking processes occupy restricted locations, as follows. Immediately inside the encircling melt-out till, a zone of flow tilis is found. Melt streams are located at the foot of the flow till-mantled slope, producing narrow (150 $\mathrm{m}$ wide) outwash trains, which merge into deltas. The central area of the topographic basin is occupied by a supraglacial lake. observations of the remaining four locations confirm that other glaciers in the vicinity, which display similar characteristics associated with surging, are developing a stagnant-ice zone of identica? appearance. The pattern of processes observed at Battyebreen is thus repeated at each site.

A simple model of depositional landscape development is proposed for surging valley glaciers in a sub-polar environment.

\section{REFERENCE}

Clapperton C M 1975 The debris content of surging glaciers in Svalbard and Iceland Journal of Glaciology 14(72): $395-406$ 